Submission to the Special Issue of Tourism Review on Destination Leadership

\title{
Leadership capacity in two Brazilian regional tourism organisations
}

\section{INTRODUCTION}

Leadership is arguably a fundamental plank in successful destination management, yet research examining leadership in tourism settings is rare (see study of Benson and Blackman, 2010 about distributed leadership in tourism enterprises; Dredge and Pforr, 2008 discussing private sector leading tourism destination; and Robertson, 2011 providing a description sets of behaviors necessary for lead tourism networks). Factors contributing to the lack of research are that leadership is slippery and difficult to define and its dimensions of analysis remain heavily debated (see Burns, 1978; Bass and Bass, 2008). As a result of this debate, and the competing theories of leadership that have emerged, the leadership literature has tended to be introspective, contained within and dominated by business and organisational studies. The same criticism could also be pointed at the tourism literature, which has tended to examine destination management practices and governance without drawing from the rich insights contained within the leadership literature. Given that current destination management discourses suggest that good leadership involves power sharing, collaboration and joint resourcing arrangements (see Jamal and Getz, 1999; Hall, 2011), this paper provides a timely contribution that draws together the regional tourism management and leadership literature.

Drawing from a range of classic works, leadership has been broadly defined as the process through which a leader (individual or entity) is able to achieve a set of mutually agreed goals through the mobilisation of others (Burns, 1978; Bass and Bass, 2008; Chemers, 1997). However, in the context of regional tourism, establishing mutually agreed goals amongst a variety of actors, where the line of command and control is not always clear, makes leadership a problematic concept (Dredge, 2009; Bramwell and Lane, 2011; Jamal and Getz, 1995). As a result, the diversity of tourism actors involved in destination management and the complexity of the tourism management setting mean that more attention on regional tourism 
leadership is not only warranted but long overdue. Furthermore, given governments' increasing reliance on regional tourism organisations (RTOs) in delivering state tourism and economic development policy objectives, understanding more about leadership capacity by RTOs is crucial (Jenkins, 2000; Bramwell and Lane, 2011). This paper examines the leadership practices of two Brazilian RTOs using an exploratory case study.

In Brazil, and across the world, individual and institutional leadership in regional tourism are becoming increasingly important. Since the 1990s Brazil has introduced a range of social, political and institutional reforms to modernise its economy and facilitate economic and social progress (Lohmann and Dredge, 2012). New forms of regional tourism governance incorporating public-private partnerships are being introduced, institutional responsibility is moving from central to regional levels, and the leadership baton has been passed from the national government to RTOs (de Araujo and Dredge, 2012). Mirroring restructuring processes taking place in many countries, in Brazil some RTOs have adopted bureaucratic command and control structures (known as hierarchical governance) while others have adopted corporate structures (known as market models of governance) to operate as commercial entities. The adoption of different governance models provides an opportunity to compare leadership under different governance scenarios and enables us to answer two important questions that provide the focus of this paper: "What are the characteristics of leadership as conceptualised by actors in regional tourism?" and "How is leadership operationalised in different governance models?

As an embedded case study this paper explores RTO leadership in two sub-case studies operating in the same geographical region in Brazil. The first RTO is 'Instituto Estrada Real' (hereafter referred to as the IER), and the second is the 'Associação Circuito do Ouro' (hereafter referred to as the ACO). Both are not-for-profit organisations. The IER is established and supported by the private sector, while the ACO is established as an initiative of the State Tourism Department of Minas Gerais. The IER is characterised as having a market-oriented governance structure, with the ACO being characterised as having a hierarchical (government-led) governance structure (see Beaumont and Dredge, 2010; Hall, 2011). Both RTOs face very different leadership challenges, despite the fact that they have the same territory with 
similar socio-political, cultural and economic contexts.

This paper draws from two broad and intersecting bodies of literature: leadership theories and regional tourism management. Drawing from secondary data analysis and semi-structured interviews, the findings illustrate that the main actors involved in each regional tourism destination have different perceptions of leadership, making both theoretical and applied contributions to understanding regional tourism leadership. While the case study focuses on Brazil, the findings are likely to be relevant to many developing and developed countries.

\section{LEADERSHIP THEORIES AND ELEMENTS}

\section{Trait, behavioural, contingency and integrative theories}

According to Dalglish and Miller (2010), leadership theories can be categorised into four main streams: trait, behaviour, contingency and integrative theories. Other authors have pointed out that each set of theories is built around the interactions of five key elements of leadership: the leader, the external context, the organisational structure, the followers and the goals (Northouse, 2009). In each of these sets of theories the capacity of an individual or entity to demonstrate leadership is explained differently depending on which of these above elements is the focus of explanation.

In trait theory, for example, the notion of capacity relies on the personal qualities of the leader. For this reason within trait theories leadership capacity is framed around the personal characteristics of the leader, including (Fleury, 2002) physical traits (e.g. appearance such as height, weight and voice), skills (e.g. intelligence, communication and knowledge) and personality (e.g. extraversion, dominance, confidence and emotional control). In essence, trait theory provides some insights into the characteristics of individual leaders, but the context in which leadership is performed and the roles of other actors (e.g. followers) are assumed to be static.

In behavioural theory leadership capacity depends on how the leader behaves or enacts leadership. Behavioural theory is interested in evaluating the behaviour of leaders in identifying broad leadership styles and in applying this learning through 
professional development programs (Bernal, 2009). The focus of behavioural theories of leadership has been on identifying universal practices that can be developed and on reflective processes though which additional skills can be incorporated (Kunz and Hoy, 1976).

In contingency theory the external context and organisational structure determine how leadership is enacted. Hence, optimal or leadership capacity depends on the situation, and the external context plays a significant role in shaping leadership ( Fiedler, 1973). Thus, leadership theories began to take into account the external context, such as exogenous influences, environmental variables, uncertainty, and interdependence of stakeholders, technology and innovation (Lawrence and Lorch, 1986). Another important element in contingency theory is a strong association between leadership and organisational structure; where the organisational structure is a good fit with the leadership style there is higher performance (i.e. leadership capacity).

Integrative theories attempted to combine trait, behavioural and contingency theories to explain leadership (Avolio, 2007; Stogdill, 1974). One of the best known of these integrative leadership theories is transformational theory (Dalglish and Miller, 2010; Drath et al., 2008). Central to transformational theory is the differentiation between two contrasting types of leaders: transactional and transformational leaders. The transactional leader provides subordinates (followers) with what they value, which could be pay, recognition, praise, feedback or promotion, in exchange for what the leader values, such as increased sales or greater productivity. In contrast, transformational leaders motivate their followers to perform beyond expectations by evoking followers' higher order needs and values, so they are not just working for the organisation but also for their own intangible benefits and goals (Dalglish and Miller, 2010; Drath et al., 2008). Some authors argue that leaders can be both transformational and transactional, suggesting that the most capable leaders utilise both behavioural styles (Avolio, 2007).

Also falling within the integrative theories of leadership is distributed leadership (also known as shared leadership). This theory argues that leadership is distributed over time and space in individuals and agencies, and has become an increasingly popular explanation for leadership in networked social environments (Spillane et al., 2004). 
Yukl (2002) has noted that distributed leadership does not require an individual who can perform all of the essential leadership functions, only a set of people who can collectively perform them. While important decisions may be shared by several members of a group, some leadership functions may be allocated to individual members, and a particular leadership function may be performed by different people at different times. The leadership actions of any individual leader are much less important than the collective leadership provided by members of the organization (Yukl and Gronn, 2002). A distributed leadership perspective does not preclude the role of individuals but recognizes the inclusive and collaborative nature of the leadership process. One designated leader may be central to the orchestration of policy formulation, however, on their own they are unable either to reshape the context or formulate the content of change and determine new practices (Oborn et al., 2013).

These above theories of leadership provide useful background to this research. However, it is important to acknowledge that these theories have been derived from corporate environments where leadership elements are clearly positioned. Leadership within the context of RTOs is quite different to a corporate entity, so it is necessary to be mindful of the ambiguity embedded in terms such as leaders, followers, organisational structure and goals which might be defined quite differently from common interpretations in the business leadership literature. For example, in this study the leader of an RTO might be the CEO, but it could also be the collective Board of Directors or the Chairperson of the RTO Board. Furthermore, the tasks of an RTO are broad and different actors not specifically endowed with a formal leadership position might take a leadership role to achieve a particular set of goals, for example marketing or investment attraction, but at the same time also follow the CEO or Chairperson of the RTO Board on other matters. These ambiguities and the challenges of studying leadership capacity by RTOs suggest that while traits, behavioural, contingency and integrative theories of leadership provide important background understanding it is important to understand regional tourism leadership within its context.

\section{Challenges to identifying leadership elements within the regional tourism context}


Understanding the ambiguity surrounding the concept of leadership in regional tourism is important in determining the research approach. For example, as noted above, regional tourism actors can be both leaders and followers at different times or simultaneously when different issues are being dealt with. Similar ambiguity exists in the notion of goals where the traditional view is that leadership involves the pursuit of shared goals. However, the interests and values of actors involved in regional tourism are not only diverse, but they may also be unique, competitive and/or inconsistent (Beaumont and Dredge, 2010). Relationships between regional tourism actors are often volatile and actions are often motivated by parochialism and self-interest rather than collective, shared interests. Regional actors see problems and solutions differently and, for this reason, often prioritise and seek different goals, which in turn manifests in pressures on the distribution of power and resources (Zahra, 2011). As a result, it is a complex task to understand where leadership capacity resides and how it is practiced in these messy public-private spaces of regional tourism governance (Bramwell and Lane, 2011; Dredge, 2009; Jamal and Getz, 1995).

Similarly, it is not easy to determine where the leadership baton is best placed in regional tourism. There are divergent positions about whether the public or the private sector is better placed or more capable of providing leadership in regional tourism. Some authors, such as Vernon et al., (2005), argue that the public sector is better placed to lead because it can facilitate the development of strategic directions and innovation as opposed to a fragmented private sector. Moreover, the public sector can undertake various roles such as the initiation of partnerships, organise marketing activities and provide resources to support product development. In such cases governments often overcome industry fragmentation by implementing a structure of "make believe" that appears to hand leadership to the RTO but, in fact, the leadership role is retained by government through drip-feeding resources and manipulating membership of tourism boards (Beaumont and Dredge, 2010; Robertson, 2011). Nepal (2009) argues that when the public sector takes the leadership baton, interactions between the state and business interests dominate and it is possible that interactions between other actors (e.g. community groups and not-for-profit organisations) become marginalised. 
These discussions and recommendations about regional tourism management have taken place within an increasingly neoliberal public management context wherein governments have been keen to develop public-private partnerships and prioritise business interests (Jenkins, 2000; Bramwell and Lane, 2011). This logic also suggests that placing leadership in the hands of RTOs has some advantages when compared with leadership provided by either public or private sectors. RTOs are comprised of a range of actors (e.g. public, private and non-government actors) and because of this a broad range of skills, knowledge and expertise can be drawn upon. As a result of these ambiguities and challenges in defining leadership, in deciding where to look for it and how to recognise it as the "hard" and/or "soft" power to lead, there are certain challenges for the way this research is framed.

\section{RESEARCH APPROACH}

\section{Conceptualising leadership for this study}

This research seeks to understand the phenomena of leadership and to interpret it within the everyday activities of regional tourism actors. We interpret leadership capacity as a process, an outcome and a concept that is at the same time both tangible (such as a formal position) and intangible (such as an experience, a conversation or the "soft" power of a charismatic actor). It is the result of negotiation, the sharing of meaning and actions (collective or individual) taken towards some shared goal. As a result, we reject the notion that leadership is something that can be defined and verified through the identification and measurement of universal variables using positivist or post-positivist approaches. This ontological positioning influenced the adoption of a mixed methods qualitative research strategy, whereby the gathering of empirical evidence and the creation of understandings about leadership were undertaken using secondary research and semi-structured in-depth interviews (see Patton, 2002).

The research adopted an embedded case study approach, which permitted the comparison of leadership in two different RTO settings. An embedded case study is a case study containing more than one sub-unit of analysis (Yin, 2003). In this research the sub-units were two RTOs operating under different governance regimes within the 
same geographical area. According to Yin (2009), the comparative case approach is a method suitable for the study of processes which involve holistic analysis. A case study is an empirical enquiry that investigates a contemporary phenomenon within its real-life context and is especially useful when the boundaries between phenomenon and context are not clearly evident. Furthermore, when a phenomenon can be studied using more than one case the evidence is often considered more compelling and the method is considered more robust (Yin, 2009). Another advantage of using contrasting sub-cases within a single case is that it enhances the possibility of identifying the variations or contingencies under which the phenomenon manifests itself (Miles and Huberman, 1994).

The characteristics of the case were first explored and described using secondary sources of information such as online searches of the ACO and the IER policy documents, journal articles, magazines articles and government reports. This background "casing" provided the detailed setting within which the two sub-cases of leadership (i.e. the IER and the ACO) reside. The main reasons for choosing these RTOs were: a) both RTOs have an influence over the same region of the State of Minas Gerais, providing a major advantage as almost all tourism actors can reflect on the leadership capacity of both RTOs; b) leadership has been established over a period of almost ten years, providing the opportunity for interviewees to reflect on the results obtained in the different sub-cases; and c) these RTOs provide an accumulation of experience and empirical material for comparison and analysis.

\section{Data collection and analysis}

The study employed two data collection methods: desktop analysis and interviews. This study gathered information from the RTOs' executives and the different actors/followers involved with both RTOs in order to obtain their perceptions about effective leadership in regional tourism destinations. A total of 14 in-depth semistructured interviews with two different types of participants were interviewed in two stages. First, the CEO and executive manager from each RTO were interviewed $(n=4)$. These CEOs and managers were considered key leaders by virtue of their formal positions, and were well informed about the subject matter (Punch, 2005). 
After the four leaders were interviewed other actors who were common to both RTOs were interviewed, including private sector $(n=3)$, public sector $(n=3)$ and third sector $(n=4)$ representatives. Empirical material collection occurred in Brazil in January and February 2013.

The primary interview data collected for this research was analysed using three techniques from Miles and Huberman's qualitative analysis model (1994): empirical materials reduction (associated with the distillation of empirical materials into identifiable categories, themes and concepts); empirical material display (ideographic presentations of the categories, themes and concepts); and conclusion drawing and verifying (by constantly comparing empirical data against other research qualitative theory is built). The categories, themes and concepts were derived from the literature review reported above and NVivo 10 content analysis software) was used to store, access, manage and analyse the data.

\section{CASE STUDY CONTEXT}

Since the late 1980s, after almost 20 years of authoritarian dictatorial rule (19641985), Brazil went through a profound process of re-democratisation and opened its door to economic neoliberalisation and globalisation. Among the resulting changes, it pursued financial decentralisation and introduced reforms in public administration and governance structures, which sought to minimise the historical dominance of a heavyhanded bureaucracy. These changes brought various challenges for Brazil's political leadership, including the need for institutional structures and processes to reposition the country as more economically accessible and globally competitive (Lohmann and Dredge, 2012).

In the 1990s, Brazil shifted its attention to tourism as a regional development tool, adopting strategies aligned with neoliberalism and new public management. This included an attempt by the state to withdraw from direct involvement, a shift towards facilitating and empowering business and non-government stakeholders to develop tourism, stimulating capital investment and market demand rather than direct investment in tourism products (de Araujo and Dredge, 2012). Since the 2000s, the 
Brazilian Government has invested in the decentralisation of tourism and in 2003 created a Tourism Regionalisation Program to hasten this process.

Official tourism governance structures in Brazil comprise four levels. First, at the federal level, the Ministry of Tourism is the major tourism agency. The National Tourism Council is a body of industry representatives appointed by the Minister of Tourism, which provides guidance and oversight to the Ministry of Tourism. Second, state tourism agencies are responsible for implementing state-wide tourism policies and are usually advised by their respective state tourism industry forums. Third, at the regional level, RTOs have been created mostly by state governments in an effort to promote regional clustering. Fourth, at the local level, usually a Municipal Tourism Department or similar unit exists. Local tourism industry councils (known as COMTURs) are appointed to provide guidance to the municipal agency. Within this context, RTOs have an important leadership role in regional tourism governance in Brazil. The Brazilian Government, for example, is increasingly advocating that leadership of regional tourism does not remain in the hands of public authorities and that the influence of government should be reduced in order to avoid bureaucracy and corruption. In general, RTOs are not-for-profit organisations that are based on publicprivate participation although the balance varies. RTOs can have different legal structures such as forums, councils, associations, committees and institutes (Ministério do Turismo, 2012). Given these diverse RTO arrangements it is not surprising that leadership practice can vary from case to case and from context to context.

The study area for this case study is a geographical region in the State of Minas Gerais and comprises 19 municipalities. Most of these cities were built during the gold rush era in the $18^{\text {th }}$ Century, a period that consolidated the colonisation of the country. These destinations are rich in cultural heritage such as museums, churches, cultural centres, archaeological sites, farms, sanctuaries and old houses. One of these towns is Ouro Preto, a world heritage site. Both RTOs analysed in this research operate over seven municipalities within the same geographical area.

\section{The ‘Associação Circuito do Ouro’ (ACO)}


The ACO was officially established in 2001, with its creation being encouraged and subsidised by the state government. The ACO has a legal structure as a not-for-profit association maintained through membership fees paid by 17 municipalities. Its main objective is to support sustainable tourism development within 19 local destinations (Ricci, 2012). According to Secretaria de Estado de Turismo de Minas Gerais (2011), the ACO is one of the most important RTOs of Minas Gerais, receiving support from the state government for tourism signage, training courses, strategic plan development and promotion (Trentin and Fratucci, 2011). The ACO has adopted a hierarchical bureaucratic tourism governance model (see Hall, 2011) following policies from the Ministry of Tourism that see it taking responsibility for providing infrastructure and market planning.

\section{The 'Instituto Estrada Real' (IER)}

The IER is responsible for the development of tourism in the Estrada Real (ER), which is a tourism product in the form of an ancient royal road opened up more than 300 years ago to transport gold and diamonds from the Minas Gerais countryside to the port of Rio de Janeiro. ER's tourism products are found along a 1,600 km route that crosses into approximately 199 municipalities and covers an area of $80,000 \mathrm{~km}^{2}$ (Instituto Estrada Real, 2012). According to Secretaria de Estado de Turismo de Minas Gerais (2011), ER is the most important tourism product in the State of Minas Gerais. The IER was established through the initiative of FIEMG, the Federation of Industries, Commerce and Tourism of Minas Gerais (a peak industry group), with the aim of strengthening the productivity and sustainability of the tourism supply chain.

The IER was established as an NGO to achieve the sustainable development of its constituent municipalities and to implement projects that promote tourism along the ER. Typically these projects are aimed at improving the quality of services, tourism signage and infrastructure along the road, as well as activities to induce tourism development (Instituto Estrada Real, 2012). The IER has set up five local branches to better manage its activities and initiatives across the region. One of these sub-regions (Ouro Preto branch) comprises 22 cities and includes seven municipalities that coincide with those belonging to the ACO. The IER has adopted a market type of tourism governance wherein the industry sets the strategic direction and takes responsibility for implementing actions (see Hall, 2011). 
In sum, while located within the same geographical area, having overlapping tourism products and seven municipalities in common, both RTOs face very different leadership challenges. Despite sharing many of the same socio-political, cultural and economic characteristics their governance and organisational arrangements produce different constraints and opportunities for leadership capacity. Both RTOs also present unique characteristics. For example, as previously discussed, the ACO was established as an initiative of SETUR (the State Department of Tourism) while the IER was established by the FIEMG and supported by the private sector. As a consequence the ACO has a strong public sector influence, relying on technical and logistical support provided by SETUR, while the operation and management of the IER is strongly influenced by the private sector. The ACO is maintained through fees paid by 17 municipalities, while the IER has financial support from the industry (i.e. FIEMG). The ACO has a legal structure as an association, while the IER is an NGO. These characteristics are summarised in Table 1.

Table 1 Comparison between the ACO and the IER

\begin{tabular}{lcc}
\hline Main Characteristics & ACO & $\begin{array}{c}\text { IER (Ouro Preto } \\
\text { Branch) }\end{array}$ \\
\hline Geographical area & \multicolumn{2}{c}{$\begin{array}{c}\text { State of Minas Gerais, Brazil } \\
\text { Same characteristics }\end{array}$} \\
$\begin{array}{l}\text { Socio-political-economic and cultural background } \\
\text { Number of municipalities in common }\end{array}$ & \multicolumn{2}{c}{22} \\
Number of municipalities involved & 19 & FIEMG \\
Established and supported by & SETUR & Private sector \\
Strong influenced by & Public sector & NGO \\
Legal structure & Association & Market \\
Governance model (structure) & Hierarchical &
\end{tabular}

\section{FINDINGS}

As previously discussed, two important questions provide the focus for this research: "What are the characteristics of leadership as conceptualised by actors in regional tourism?" and "How is leadership operationalised in different governance models? The findings are discussed below:

\section{How do actors perceive leadership in regional tourism?}


The analysis revealed four dominant themes with respect to how actors perceive the capacity of the RTO to lead: (1) the capacity to produce results; (2) the capacity to mobilise followers (these two themes strongly relate to notions of transformational leadership and, at same time, related with the IER leadership context); (3) articulation and communication of goals and actions; and (4) the capacity to clearly articulate roles and responsibilities. These two factors are strongly related to notions of distributive leadership, particularly within the context of the ACO.

\section{The capacity to produce results}

The capacity to produce visible, concrete results is a characteristic of transformational leadership theory and was identified by all interviewees as a key characteristic of RTO leadership. However, there is a strong tendency in the region (both in regards to the ACO and the IER) for "much talk and limited results", especially visible results that are clearly identified and articulated:

There's a lot of 'bla bla bla' and little action, little reality, much talk-talk and little reality, many small things and much eye candy [...], but, in reality concrete results do not happen. (RTO representative)

Some results (goals of the RTO) are not quickly achieved, nor are they easily measured. Some actors recognise this in statements such as: "The result [goal] of tourism leadership is in the long term" (third sector representative), and "They want results very fast; however, within the tourism context, results are not so immediate" (public sector representative).

The challenge of how to produce fast, tangible results is not always possible in a regional context where organisational arrangements are complex. For this reason interviewees also identified other essential interdependent characteristics of leadership that go hand-in-hand with the capacity to deliver results, which are discussed below.

\section{The capacity to mobilise followers}

The capacity to mobilise actors was also identified as an important characteristic of RTO leadership. According to those interviewed, this included the capacity to 
mobilise leaders in other sectors and networks, as well as other actors within the RTO; the capacity to mobilise resources (e.g. financial, political, in-kind support); and the capacity to mobilise or leverage relationships. This leadership trait is also a characteristic of transformational leadership requiring, over time, a high level of motivation and commitment from followers.

However, in this case study region interviewees pointed out some historic-cultural background that hinders the capacity to mobilise due to the belief that there is nothing that can be done to support tourism development:

\footnotetext{
Mobilization is hard and people do not participate. There exists a culture in this region that everything is ready [due to the historical heritage], and it is not necessary to do any work, they rely on spontaneous tourism, forgetting about the market competitiveness that reigns today and, for the destination to be competitive, it needs a high level of planning and quality service provision. Mobilisation, this is the biggest challenge for us and for all involved with [tourism] governance ... [it] is the most difficult thing. (Third sector representative)
}

\section{Articulation and communication of goals and actions}

The majority of interviewees identified the capacity to articulate goals and actions as another important characteristic of RTO leadership, which is associated with theories of distributed leadership. Mobilising followers (discussed above) and the capacity to articulate common goals and align these goals with clear actions are closely related. It is through continual collaborative dialogue between RTO leaders and followers that goals can be consolidated, actions identified and actors commit to this clear vision.

However, the organizational complexity of the RTO setting may exacerbate difficulties in establishing the collaborative dialogue needed to strengthen the leadership capacity of the RTO. The tourism industry is fragmented; it involves many sectors and requires actions from a range of actors inside and outside tourism to achieve results. As one RTO leader stated, “[...] tourism planning is $70 \%$ of articulation and $30 \%$ of execution. It is necessary to drive communities and the tourism industry through regional coordination". However, in order to achieve 
practical outcomes it is necessary that actors understand how the tourism production chain works:

\footnotetext{
Articulation involves, for example, understanding that the role of the local council tourism department is to facilitate tourism activity as a whole. It [the tourism department] does not run the transport sector; this cannot be put in its hands. And people often think that a tourism department has to set up package tours but this role belongs to the market, to tour operators. (RTO representative)
}

These perspectives suggest that understanding the multi-sectoral complexity of the tourism sector and that roles and responsibilities for implementing actions can lie outside the direct control of RTOs is essential for developing the capacity of an RTO to lead. Following on from this, analysis also revealed that there is a need for clear roles and responsibilities to be articulated if RTOs are to establish leadership of tourism in the region.

\section{The capacity to clearly articulate roles and responsibilities}

The capacity to mobilise, to clearly and collaboratively articulate goals and to implement integrated actions focuses attention on the role of actors (both leaders and followers) in effective leadership in RTOs. That is, because of the complexity of regional tourism and the distribution of roles and responsibilities across different sectors interviewees identified clarity of roles and responsibilities as being a significant factor in effective leadership. This observation was closely aligned with distributed leadership theories:

The problem [of understanding an RTO's capacity to lead] is that within the tourism context there are many roles that have not been properly defined. Everything is mixed up; there is no such separation of roles. (Third sector representative)

As one interviewee observed, the lack of clearly defined roles also problematises the evaluation of RTO performance: 
What the RTO's role is, and what it is not, is not clear, so we do not have defined responsibilities. If you do not have these responsibilities well defined, how will someone evaluate the capacity of the RTO's leadership? (RTO representative)

This interviewee went on to explain that when an entity does not know exactly what its role is, it can inadvertently interfere with the work of another individual or entity. This can lead to confusion among other actors in regards to who does what. Further, not having well defined roles can create leadership gaps where neither one nor the other does what needs to be done: "We have SETUR, IER, ACO [...] and each has its own role, and each with its function, and if one is missing, [its absence] ends up harming others" (Private sector representative).

While the capacity to define specific roles was identified by the majority of interviewees as a characteristic of leadership, one participant explained the challenge further by pointing to the need for a dynamic policing and re-setting of roles and responsibilities when several actors/entities interact over time as issues change:

\footnotetext{
You must remember them [their roles] all the time: this is your role, my role is another one - to avoid confusion. If ABIH [Hotel Association] starts taking the role of the [peak] industry association, then both of them lose focus. It gets pretty confusing and you have to stop, think and distinguish which is the task of each one. (Third sector representative)
}

\section{Differences in the leadership practices of the IER and the ACO}

The second question this research addresses is whether there are differences in the leadership practices of the two RTOs and what are the advantages and disadvantages of each governance structure. The findings reveal consensus among respondents that the ACO has a natural alignment with the tourism functions of federal, state and local governments. This alignment allows the ACO to act like an extension of SETUR. As stated by one of the managers working for the ACO, "[...] our main strength is that we represent public policy, and this facilitates much of our relationship with associates, which are the municipalities". Thus, municipalities are the main members associated with the ACO and through this alignment can access benefits such as the 
'Touristic Goods and Service Tax' (a program of fiscal incentives). The same interviewee pointed to a transactional mechanism that enabled the ACO to take a leadership role:

The municipality needs to be associated with us to get the Certificate of Association. This Certificate has a great value for any destination and it is worth a lot to us, not as a financial resource, but mainly as an operational resource [to get the municipalities on-side].

This transactional mechanism - called an operational resource in the RTOs' language - creates a form of transactional leadership whereby municipalities are required to participate in the association. This transactional relationship between the leader, the ACO and the followers (municipalities) also allows the ACO to access and enter into dialogue with the various tourism governance structures in the different municipalities. The ACO has proximity to federal, state and local governments and, for this reason, its leadership promotes integration with tourism public policies. As stated by one of the interviewees from the ACO, "the ACO is now like a tool that translates public policy to municipalities, we can facilitate the implementation of tourism policies in the municipalities".

The ACO's organisational context also leads to some leadership issues. Firstly, one negative aspect is the political and financial dependence to the public sector. Financial dependence exists as municipalities pay monthly fees (approx. US\$500) to the ACO and the ACO needs to compete for public funds for project implementation from both the state and federal levels. Political dependence is due to the intermediate hierarchical position of the ACO. The ACO also has difficulties in mobilising the private sector for several reasons. First, because the ACO is an association that has strong ties with government this can negatively affect the legitimacy and representativeness of the association from an industry perspective. Second, many policies are determined by federal or state governments, which might not necessarily represent the goals of regional businesses. Lastly, the ACO has difficulty in presenting results at the speed required by the needs of the private sector. 
In regards to the IER, there is a consensus among interviewees that it has been receiving support from the peak state industry association, FIEMG. As one manager for the ACO observed, "FIEMG presence brings a validation for everything that the IER has done and this enriches all its leadership processes. I think that FIEMG presence endorses and it is recognised as a very important one". FIEMG not only lends its name, but also invests substantial funds in the IER. This has enabled the IER to hire well-qualified professionals and technical staff and to seek expertise when necessary for the development of technical tourism projects. In turn, this increases the IER's ability to attract funding from various sources, including the Ministry of Tourism and the Inter-American Development Bank (IDB):

The FIEMG invests money in the IER because FIEMG sees in the IER an entity capable to identify new business opportunities to several economic sectors. When tourism grows, all sectors of the economy grow. We [the IER] undertook a five million dollar project in which the IDB has provided one-third of the investment, the state government another third and the FIEMG the final third. (IER representative)

Interviewees also identified that the majority of the investment made by IER was in the promotional and marketing aspects of Estrada Real (ER). It is not a surprise that massive exposure in the media brought an awakening mobilisation in the community and regional actors around the ER idea:

Despite all hits and misses, the experience of the Royal Road [ER] proposed by the IER, it ended up producing a 'wake-up call' in the region, as if other stakeholders were not doing their bits. SETUR and associations recognise the efforts made by the IER, because they brought a very professional approach. (Public sector representative)

The lack of experience with the nuances of tourism activity made the IER prioritise just the promotional marketing of the ER. Most likely the IER was expecting that the tourism product associated with the ER would be structured by other regional actors:

Problems started happening when tourists came to this region and they were thinking that everything in terms of the tourism product was 
done, and they were surprised because there was not even a road to walk. Then, the IER put the foot on the brake in regards to promotional marketing and realised that they had to work on structuring of the road and destination. (Third sector representative)

This same institutional context of financial autonomy has led the IER to act in the region in isolation in relation to the other actors due to a perception that it is well funded by private sector investors:

The problem is that the IER does many things without linking with the ACO or any other RTO. They run their own business. This behaviour leads to confusion because, sometimes, they end up doing the same thing that the ACO could do, or the ACO could support. (ACO representative)

Table 2 compares the transformational and distributive aspects of leadership within both the ACO and the IER. The four dominant themes identified from the interviews are also represented.

Table 2 Leadership in the context of the ACO and the IER

\begin{tabular}{|c|c|c|c|}
\hline $\begin{array}{c}\text { Integrative } \\
\text { theories }\end{array}$ & $\begin{array}{c}\text { Four dominant } \\
\text { themes }\end{array}$ & The ACO & The IER \\
\hline & $\begin{array}{l}\text { Capacity to } \\
\text { produce results }\end{array}$ & $\begin{array}{l}\text { Results are defined in terms of } \\
\text { implementation of public } \\
\text { policies }\end{array}$ & $\begin{array}{l}\text { Results are defined in } \\
\text { terms of capacity of } \\
\text { attracting tourists }\end{array}$ \\
\hline $\begin{array}{c}\text { Transformational } \\
\text { leadership }\end{array}$ & $\begin{array}{l}\text { Capacity to } \\
\text { mobilise } \\
\text { followers }\end{array}$ & $\begin{array}{l}\text { Mobilises public actors and } \\
\text { community through organic } \\
\text { alignment with the different } \\
\text { levels of government tourism } \\
\text { structure. Difficult in mobilising } \\
\text { private actors: lack of } \\
\text { legitimacy and } \\
\text { representativeness from industry } \\
\text { perspective. Difficulty to } \\
\text { present results at the speed } \\
\text { required by private sector. }\end{array}$ & $\begin{array}{l}\text { Mobilises private actors } \\
\text { and community through } \\
\text { strong promotional } \\
\text { marketing and credibility } \\
\text { from FIEMG. Isolation in } \\
\text { relation to the other actors }\end{array}$ \\
\hline $\begin{array}{l}\text { Distributive } \\
\text { leadership }\end{array}$ & $\begin{array}{l}\text { Articulation and } \\
\text { communication of } \\
\text { goals and actions }\end{array}$ & $\begin{array}{l}\text { Relies on its own hierarchical } \\
\text { position and the support of the } \\
\text { SETUR. Political cycles result } \\
\text { in government and policy shifts } \\
\text { which difficult implementations }\end{array}$ & $\begin{array}{l}\text { Relies on its own } \\
\text { financial capacity and } \\
\text { FIEMG support. Isolation } \\
\text { in relation to the other } \\
\text { regional actors }\end{array}$ \\
\hline
\end{tabular}


Capacity to

clearly articulate

roles and

responsibilities
Better understanding of regional

policies, resulting in better capacity to provide clear roles and responsibilities.
Acts in isolation from other actors, resulting in a lack of capacity to provide clear roles and responsibilities

\section{DISCUSSION AND CONCLUSIONS}

The aim of this paper was to provide insights into leadership capacity of two different Brazilian RTOs using an exploratory case study. Two questions provided the focus for the case study research: "What are the characteristics of leadership as conceptualised by actors in regional tourism?" and "How is leadership operationalised in different governance models?" In relation to the first question, the analysis revealed four dominant themes with respect to how actors perceive the capacity of RTOs to lead: (1) capacity to produce results; (2) capacity to mobilise followers; (3) articulation and communication of goals and actions; and (4) articulation of roles and responsibilities. The findings suggest that different governance arrangements can have an important impact on the capacity of RTOs to exercise leadership in regional tourism. In particular, the study concluded that while the IER (and its market or industry-led governance arrangements) provides better transformational leadership capacity, particularly in regards to producing results and mobilising followers, the latter is only achieved with those directly linked to the IER's projects financed by the private sector. In this way the capacity of the RTO to lead (and mobilize followers) is limited to and dependent upon the extent of its industry network. However, tourism actors outside the influence of the IER perceive this RTO to be operating in isolation from the broader policy context.

Alternatively, the ACO's capacity to lead is shaped by the distribution of roles and responsibilities across various layers of government, and the extent of those government actors in implementing policy. As a bureaucracy-led governance structure, the ACO's leadership was characterised as distributed in that leadership was enacted via its capacity to mobilise a wide range of public sector actors and community at different levels (national, state and local). Further, the strength of the transactional mechanisms (such as a Certificate of Association, which enables local governments to access financial incentives to develop tourism) means that the ACO 
has, potentially, extensive capacity to lead by distributing roles and responsibilities (see Table 2). However, the ACO's leadership capacity is affected by political cycles and its inability to work at the speed with private sector demands.

Analysis of the second question revealed that the rules, routines, structures and processes that characterise an RTO's operation significantly shape the capacity of RTOs to lead. These capacities from both the ACO and the IER are complementary in terms of effective leadership. Both RTOs face different leadership challenges, constraints and opportunities. However, at the same time it means that there is scope to develop joint collaborations, power sharing and resourcing arrangements. Each RTO presents different yet complementary leadership capacities, skills and strengths. The governance structure of the ACO is shaped and aligned with the structure of government (federal, state and local), facilitating relationships, proximity and dialogue with followers and integrating with tourism public policies. The governance structure of the IER is shaped and aligned with the private sector, facilitating financial capacity, promotional marketing and credibility, particularly through the engagement with the FIEMG. While the IER provides efficient mechanisms of mobilisation, the ACO is regarded as providing well-defined roles to other actors with more proximity being achieved across the broader tourism actors.

It is also worth adding that the regional tourism context is a complex one. The line of command and control is not always clear, with roles and responsibilities being distributed across a range of actors. In addition, while formal leadership roles exist, leadership is distributed across multiple actors. As a result, due the context of this specific study case, at least three issues should be considered: (1) transformational leadership is necessary in order to promote not only mobilisation, but also fast and tangible results; (2) distributed leadership plays an important role, particularly in regards to the community participatory engagement that has characterised official tourism programs in Brazil (de Araujo and Dredge, 2012); and (3) cooperation and collaboration between RTO leaders can be one alternative used to achieve leadership in a regional tourism destination.

This paper explores aspects of leadership specific to Brazilian RTOs and suggests that leadership capacity is influenced by tourism governance arrangements. Specifically, 
networks and the functional relationships between industry, government and community (i.e. whether they are focused on hierarchical governance such as coordination across levels of government or market-led forms of governance focusing on industry relations), appear to have important implications for the capacity of RTOs to mobilise different actors and what sort of results are pursued (e.g. attracting tourists or implementing public policy). Whilst this research did not seek to analyze governance arrangements, there is a clear relationship between the type of governance arrangement and an RTO's capacity to lead. This in turn points to the importance of further empirical research examining how RTOs can manage their networks to enhance leadership in four key areas: (1) capacity to produce results; (2) capacity to mobilise followers; (3) articulation and communication of goals and actions; and (4) articulation of roles and responsibilities.

Finally, it is important to note that, as a case study these findings are not generalizable beyond the case. However, these findings can be used as a lens to explore the capacity of RTOs to lead regional tourism in other jurisdictions. In particular, the paper points to the importance of further work including studies that explore: How should cooperation and collaboration between RTOs leaders be promoted? How do the personal (i.e. individual) leadership practices of the CEOs, presidents and managers impact on the leadership practices of the RTO as an entity? And, what is the relationship between leadership, organisational culture and political control in RTOs? Clearly, if RTOs are to deliver their mooted benefits of regional development and economic growth, then more research attention to leadership practices is warranted.

\section{REFERENCES}

Avolio, B. (2007), "Promoting more integrative strategies for leadership theorybuilding", American Psychologist, Vol. 62, pp. 25-33.

Bass, B. M. and Bass, R. (2008), The Bass Handbook of Leadership: Theory, Research, and Managerial Applications, Fourth Edition, Free Press, New York, NY.

Beaumont, N. and Dredge, D. (2010), "Local tourism governance: a comparison of three network approaches", Journal of Sustainable Tourism, Vol. 18, pp. 7-28. 
Benson, A. M. and Blackman, D. (2010), “To distribute leadership or not? A lesson from the islands", Tourism Management, Vol. 32, pp. 1141-1149.

Bernal, E. (2009), “Designing transformational leadership development programmes”, Business Leadership Review, Vol. 6.4.

Bramwell, B. and Lane, B. (2011), "Critical research on the governance of tourism and sustainability", Journal of Sustainable Tourism, Vol. 19, pp. 411-421.

Bryman, A. and Bell, E. (2007), Business Research Methods, Oxford University Press, Oxford.

Burns, J. M. (1978), Leadership, Harper \& Row, New York, NY.

Chemers M. (1997), An Integrative Theory of Leadership, Lawrence Erlbaum Associates, Mahwah, NJ.

Dalglish, C. and Miller, P. (2010), Leadership: Understanding its Global Impact, Tilde University Press, Melbourne.

De Araujo, L. M. and Dredge, D. (2012), “Tourism development, policy and planning in Brazil", Lohmann, G. and Dredge, D. (Eds.) Tourism in Brazil: Environment, Management and Segments, Routledge, New York, pp. 17-29.

Drath, W. H., Mccauley, C. D., Palus, C. J., Van Velsor, E., O'Connor, P. M. G. and McGuire, J. B. (2008), “Direction, alignment, commitment: Toward a more integrative ontology of leadership", The Leadership Quarterly, Vol. 19, pp. 635-653.

Dredge, D. and Pforr, C. (2008), "Policy networks and tourism governance. Network analysis and tourism from theory to practice", Scott, N., Baggio, R. and Cooper, C. (Eds.) Network analysis and tourism: From theory to practice, Channel View Publications, Toronto, pp. 58-78.

Dredge, D. (2009), Managing Local Tourism Master Class for the NSW Northern Rivers Councils of Ballina, Byron, Kyogle, Lismore, Richmond Valley and Tweed, Southern Cross University, Tweed Heads.

Fiedler, F. E. (1973), “The contingency model: a reply to Ashour”, Organizational Behavior and Human Decision Processses, Vol. 9, pp. 356-368.

Fleury, M. T. L. (2002), As Pessoas na Organização, Editora Gente, São Paulo, SP.

Gronn, P. (2002), "Distributed leadership as a unit of analysis", Leadership Quarterly, Vol. 13, pp. 423-451.

Hall, C. M. (2011), “A typology of governance and its implications for tourism policy analysis", Journal of Sustainable Tourism, Vol. 19 No. 4/5, pp. 437-457. 
Instituto Estrada Real (2012), “Apresentação: o que é a Estrada Real?”, available at: http://site.er.org.br/ (accessed 15 February 2012).

Jamal, T. and Getz, D. (1995), "Collaboration theory and community tourism planning”, Annals of Tourism Research, Vol. 22, pp. 186-204.

Jamal, T. and Getz, D. (1999), “Community-based roundtables for tourism-related conflicts: the dialectics of consensus and process structures", Journal of Sustainable Tourism, Vol. 3, pp. 290-314.

Jenkins, J. (2000), “The dynamics of regional tourism organisations in New South Wales, Australia: history, structures and operations", Current Issues in Tourism, Vol. 3, pp. 175-203.

Kunz, D. and Hoy, W. K. (1976), "Leadership style of principals and the professional zone of acceptance of teachers", Educational Administration Quarterly, Vol. 12, pp. 49-64.

Lawrence, P. R. and Lorch, J. W. (1986), Organization and Environment: Managing Differentiation and Integration, Harvard Business School Press, Boston, MA.

Lohmann, G. and Dredge, D. (2012), “Introduction”, Lohmann, G. and Dredge, D. (Eds.), Tourism in Brazil: Environment, management and segments, Routledge, New York, pp. 1-15.

Ministério do Turismo (2012), “2007-2010 National Tourism Plan: a journey towards inclusion", available at www.turismo.gov.br/turismo/o_ministerio/plano_nacional/ (accessed $10 \mathrm{Jun}$ 2012).

Miles, M. B. and Huberman, A. M. (1994), Qualitative Data Analysis: An Expanded Sourcebook, Sage, Thousands Oaks, CA.

Nepal, S. K. (2009), “Traditions and trends: a review of geographical scholarship in tourism", Tourism Geographies, Vol. 11, pp. 2-22.

Northouse, P. G. (2009), Leadership: Theory and Practice, Sage, Thousands Oaks, CA.

Oborn, E., Barret, M. and Dawson, S. (2013), "Distributed Leadership in Policy Formulation: A Sociomaterial Perspective”, Organization Studies, Vol. 34, pp. 253-276.

Patton, M. Q. (2002), Qualitative Research \& Evaluation Methods, Sage, Thousand Oaks, CA. 
Punch, K. (2005), Introduction to Social Research Quantitative and Qualitative Approaches, Sage, London.

Ricci, I. (2002), "Entrevista Isabella Ricci”, available at www.ivtj.net/ivt/indice $\cdot$ aspx?pag=n\&id $=11757 \& \mathrm{cat}=\% \mathrm{C} 2 \% \mathrm{~A} 0 \& \mathrm{ws}=0$ August 2012).

Robertson, P. J. (2011), “An assessment of collaborative governance in a network for sustainable tourism: the case of RedeTuris", International Journal of Public Administration, Vol. 34, pp. 279-290.

Secretaria de Estado de Turismo de Minas Gerais (2011). "O que é um circuito turístico", available at: www.turismo.mg.gov.br/circuitosturisticos/informacoes-administrativas/ (accessed 22 May 2011).

Spillane, J., Halverson, R. and Diamond, J. B. (2004), "Towards a theory of leadership practice: a distributed perspective", Journal of Curricullum Studies, Vol. 36, pp. 3-34.

Stogdill, R. M. (1974), Handbook of Leadership: A Survey of Theory and Research, Free Press, New York, NY.

Trentin, F. and Fratucci, A. C. (2011), "National policy of tourism in Brazil: from municipalisation to regionalization", paper presented at International Conference on Tourism \& Management Studies, Algarve, Portugal.

Vernon, J., Essex, S., Pinder, D. and Curry, K. (2005), “Collaborative policymaking: local sustainable projects", Annals of Tourism Research, Vol. 32, pp. 325-345.

Yin, R. (2009), Case Study Research: Design and Methods, Sage, Thousand Oaks, CA.

Yukl, G. (2002), Leadership in Organizations, Pretince-Hall, Upper Saddle River, NJ.

Zahra, A. L. (2011), "Rethinking regional tourism governance: the principle of subsidiarity", Journal of Sustainable Tourism, Vol. 19, pp. 535-552. 